\title{
Inhibition by Bradykinin of Voltage-Activated Barium Current in a Rat Dorsal Root Ganglion Cell Line: Role of Protein Kinase C
}

\author{
Linda M. Boland, ${ }^{1}$ Ann C. Allen, ${ }^{2}$ and Raymond Dingledine ${ }^{1,3}$ \\ ${ }^{1}$ Curriculum in Neurobiology, 'Department of Biochemistry and Nutrition, and ${ }^{3}$ Department of Pharmacology, The \\ University of North Carolina at Chapel Hill, School of Medicine, Chapel Hill, North Carolina 27599-7365
}

The whole-cell patch-clamp technique was used to record $\mathrm{Ba}^{2+}$ currents through voltage-activated calcium channels in the clonal dorsal root ganglion cell line F11-B9. The painproducing peptide bradykinin (BK; $100 \mathrm{nM}$ ) reduced the sustained $\mathrm{Ba}^{2+}$ current in F11-B9 cells by $30 \%$. In cultures prelabeled with ${ }^{3} \mathrm{H}$-arachidonic acid and tested under ionic conditions similar to those used for recording $\mathrm{Ba}^{2+}$ currents, BK also induced a concentration-dependent, transient, 2.7fold accumulation of ${ }^{3} \mathrm{H}$-diacylglycerol. Both the elevation of ${ }^{3} \mathrm{H}$-diacylglycerol and the inhibition of $\mathrm{Ba}^{2+}$ current began within 5 sec following BK exposure, and the effective concentration range of BK was similar for the 2 responses. In whole-cell recordings, extracellularly applied 1-oleoyl-2acetylglycerol (OAG; 0.5-5 $\mu \mathrm{M}$ ) mimicked the degree of block and occluded the block of sustained current by BK. Another protein kinase C (PKC) activator, 1,2-dioctanoylglycerol (diC8), blocked $70-100 \%$ of sustained current when applied intracellularly or extracellularly at $5 \mu \mathrm{M}$, whereas extracellular application of ethylene glycol dioctanoate (5 $\mu \mathrm{M})$, an analog reported not to stimulate PKC, inhibited only $14 \%$ of sustained current. The pseudosubstrate peptide PKC19-36 (2 $\mu \mathrm{M}$ in pipette) and the lipid staurosporine (100 nM in pipette), both inhibitors of PKC, reduced the effects of maximal concentrations of OAG or BK by 55-60\%. Dynorphin A applied intracellularly $(2 \mu \mathrm{M})$ as a control for nonspecific effects of PKC19-36 did not inhibit the block of sustained current by BK. These data are consistent with the hypothesis that BK inhibits whole-cell sustained $\mathrm{Ba}^{2+}$ current in F11-B9 cells via a mechanism that involves activation of PKC.

A variety of hormones and neurotransmitters inhibit $\mathrm{Ca}^{2+}$ action potentials and whole-cell $\mathrm{Ca}^{2+}$ current in mammalian neurons in vitro (Tsien et al., 1989). Our knowledge about the biochemical pathways involved in the regulation of neuronal $\mathrm{Ca}^{2+}$ channels is, however, incomplete. Rane et al. (1989) have reported in chick dorsal root ganglion (DRG) neurons that intracellular application of specific inhibitors of protein kinase $\mathrm{C}$ (PKC) blocks the ability of norepinephrine and PKC activators to reduce the whole-cell $\mathrm{Ca}^{2+}$ current. Also, Ewald et al. (1988) have reported

Received June 12, 1990; revised Nov. 9, 1990; accepted Nov. 19, 1990.

This work was supported by NIH Grant NS23804 and by a predoctoral fellowship from the National Institute on Drug Abuse to L.M.B. We are grateful to John Miller for computer programming and to Pierre Morell and Bruce Bean for comments on the manuscript.

Correspondence should be addressed to Linda M. Boland, Department of Neurobiology, Harvard Medical School, 220 Longwood Avenue, Boston, MA 02115. Copyright (C) 1991 Society for Neuroscience $0270-6474 / 91 / 111140-10 \$ 03.00 / 0$ that long-term exposure of rat DRG cultures to phorbol esters reduces measureable $P K C$ activity and blocks the ability of neuropeptide $\mathrm{Y}$ to reduce the whole-cell $\mathrm{Ca}^{2+}$ current. Supplementary evidence includes the ability of exogenous membranepermeable activators of $\mathrm{PKC}$ to mimic the agonist-induced inhibition of whole-cell $\mathrm{Ca}^{2+}$ current (Rane and Dunlap, 1986; Werz and MacDonald, 1987; Doerner et al., 1988; Marchetti and Brown, 1988). Consistent with the potential role of PKC in the regulation of neuronal $\mathrm{Ca}^{2+}$ current, norepinephrine $(\mathrm{Ha}$ rish et al., 1986) and neuropeptide $Y$ (Ewald et al., 1989) were reported to stimulate the release of radiolabeled inositol 1,4,5trisphosphate $\left(\mathrm{IP}_{3}\right)$ from DRG cultures, implying the concomitant release of diacylglycerol (DAG), an endogenous activator of PKC (Nishizuka, 1984). The involvement of PKC in the inhibition of $\mathrm{Ca}^{2+}$ current is controversial, however (Hockberger et al., 1989; Bley and Tsien, 1990).

As reported in rat DRG neurons (Ewald et al., 1989), we found that the pain-producing peptide bradykinin (BK) inhibits a fraction of the whole-cell sustained current through voltage-activated $\mathrm{Ca}^{2+}$ channels in a DRG cell line. The clonal line F11-B9 is a subclone of the neurofilament-positive F-11 cell line previously described (Francel et al., 1987a,b; Francel and Dawson, 1988; Boland and Dingledine, 1990a). $\mathrm{Ba}^{2+}$ currents in F11-B9 cells can be separated into distinct transient and sustained components based on inactivation rates and sensitivity to holding potential, as described for the F-11 cell line (Boland and Dingledine, 1990b). The sustained component of depolarizationactivated $\mathrm{Ba}^{2+}$ current is minimally comprised of both L-type and $\mathrm{N}$-type currents because one fraction of the current, isolated at a holding potential of $-40 \mathrm{mV}$, is completely blocked by nimodipine, while another fraction is blocked by $\omega$-conotoxin GVIA.

Previous studies on other cell types have reported that BK stimulates a variety of second-messenger systems, one or more of which might be involved in the regulation of $\mathrm{Ca}^{2+}$ channels by BK. There is evidence that BK stimulates cGMP and biologically active phospholipid metabolites such as DAG, $\mathrm{IP}_{3}$, arachidonic acid, leukotrienes, and prostaglandins (for review, see Miller, 1987). Indeed, BK was reported to induce a transient production of DAG and arachidonic acid in rat DRG cultures (Burgess et al., 1989; Gammon et al., 1989) and a transient production of $\mathrm{IP}_{3}$ and a biphasic production of DAG in F-11 cells (Francel et al., 1987a,b; Francel and Dawson, 1988). Based on this evidence and the availability of useful pharmacological tools, we tested the hypothesis that BK inhibits whole-cell sustaincd $\mathrm{Ba}^{++}$current in F11-B9 cells via a mcchanism that involves activation of $\mathrm{PKC}$. 
Experiments described in this paper were designed to determine, first, whether exogenous activators of PKC inhibit the $\mathrm{Ba}^{2+}$ current in F11-B9 cells; second, whether peptide and lipid inhibitors of PKC block the effects of the PKC activators and $\mathrm{BK}$ on the $\mathrm{Ba}^{2+}$ current; and, third, whether $\mathrm{BK}$ exposure to F11-B9 cultures bathed in the external solution used to record pharmacologically isolated $\mathrm{Ba}^{2+}$ current induces the production of DAG.

Preliminary accounts of this work have been reported to the European Neuroscience Association (Boland and Dingledine, 1989) and the Society for Neuroscience (Boland et al., 1989).

\section{Materials and Methods}

Cell culture. F11-B9 cells were derived from the neurofilament-positive F-11 cell line (mouse neuroblastoma N18TG-2 $\times$ rat DRG). Stock cultures of F11-B9 cells were grown in $25-\mathrm{cm}^{2}$ tissue culture flasks in a "growth medium" consisting of Ham's F-12 supplemented with $10 \mathrm{~mm}$ glucose, $12 \mathrm{~mm}$ sodium bicarbonate, $15 \%$ fetal calf serum (FCS), 100 $\mu \mathrm{M}$ hypoxanthine, $0.4 \mu \mathrm{M}$ aminopterin, and $16 \mu \mathrm{M}$ thymidine (HAT) Cells were maintained in a humidified atmosphere of $6 \% \mathrm{CO}_{2}, 94 \%$ air at $37^{\circ} \mathrm{C}$ and were fed every other day. Stock cultures were grown until nearly confluent (7-8 d), and then were passed at a 1:10 dilution. Electrophysiological experiments were performed on F11-B9 cells (passage 2-15) that were plated on to uncoated glass coverslips and fed with either growth medium or a "differentiation medium" consisting of Ham's F-12 with $1 \%$ FCS, IIAT, $0.5 \mathrm{~mm}$ dibutyryl cAMP, and $50 \mathrm{ng} / \mathrm{ml}$ mouse salivary gland NGF (2.5S). Exposure of F11-B9 cells to differentiation medium for 1-3 d enhances the sustained component of $\mathrm{Ba}^{2+}$ current, as described previously (Boland and Dingledine, 1990b) but does not alter other properties of the $\mathrm{Ba}^{2+}$ current such as stability, activation or inactivation parameters, or sensitivity to $\mathrm{BK}$ or any other drugs tested in this study. No cells were used after more than $3 \mathrm{~d}$ exposure to differentiation medium because extensive neurite growth prevented adequate space clamp.

Voltage clamp. Macroscopic current through voltage-activated $\mathrm{Ca}^{2+}$ channels was recorded using the whole-cell configuration of the patchclamp technique (Hamill et al., 1981). Voltage pulses were $200 \mathrm{msec}$ in duration and were applied every 4-20 sec. Each depolarizing pulse was followed by $4-8$ hyperpolarizing pulses, each $1 / 4-1 / 8$ the amplitude of the depolarizing pulse. The currents elicited by hyperpolarizing pulses were summed together and used for subtraction of leak and capacitive currents. Membrane currents were filtered at $1 \mathrm{kHz}$ using an 8-pole lowpass Bessel filter (Frequency Devices, Haverhill, MA), sampled at $>2$ $\mathrm{kHz}$, and stored on a disk. Signals filtered at $20 \mathrm{kHz}$ were stored on a videotape recorder. Analysis was performed using in-house programs written in $\mathrm{C}$. For all $\mathrm{Ba}^{2+}$ currents, the sustained current was defined as the inward current at $195 \mathrm{msec}$ and was maximized by test depolarizations to $+20 \mathrm{mV}$ in $30 \mathrm{mM} \mathrm{Ba}^{2+}$. Transient current was defined as the peak current minus the sustained component and was maximized near $0 \mathrm{mV}$ in $30 \mathrm{~mm} \mathrm{Ba}{ }^{2+}$. We accepted only those experiments in which input resistance was at least $1.0 \mathrm{G} \Omega$ so that leakage current was very small. $\mathrm{Ba}^{2+}$ currents were recorded with measured series resistance ranging from 2 to $10 \mathrm{M} \Omega$, which produced a voltage error of $0.2-1.0 \mathrm{mV}$ for each $100 \mathrm{pA}$ of current. Because F11-B9 cell $\mathrm{Ba}^{2+}$ currents are typically less than $400 \mathrm{pA}$, currents were recorded without series resistance compensation, and data points on current-voltage curves were corrected for the estimated voltage error induced by the series resistance. Cells selected for electrophysiological study were isolated from other cells, had nearly spherical cell bodies about $20-30 \mu \mathrm{m}$ in diameter, and had no processes longer than the cell diameter. If there was any sign of inadequate space clamp or if the calculated voltage error grew larger than $5 \mathrm{mV}$, the experiment was ended.

Solutions. For the electrophysiological experiments, the standard internal solution consisted of (in mM) 120 Cs glutamate, 40 HEPES, 20 tetraethylammonium (TEA) Cl, 5 BAPTA, $1 \mathrm{MgCl}_{2}, 0.1 \mathrm{CaCl}_{2}$, and 0.1 GTP. The pH was adjusted to 7.3-7.35 with $\mathrm{CsOH}$, and the free $\mathrm{Ca}^{2+}$ concentration was calculated to be less than $15 \mathrm{nM}$. The internal (pipette) solution was always kept on ice and used for not longer than $6 \mathrm{hr}$. The standard external solution consisted of (in mM) $30 \mathrm{BaCl}_{2}, 80 \mathrm{TEA} \mathrm{Cl}$, 25 glucose, $20 \mathrm{CsCl}, 10 \mathrm{HEPES}$, and $0.5 \mu \mathrm{M}$ tetrodotoxin (TTX) and was adjusted to $\mathrm{pH} 7.3-7.35$ with $\mathrm{CsOH}$. External solution was warmed to room temperature prior to application to the cells. Osmolality of each solution was measured using a microosmometer (Precision Systems, Natick, MA) and was adjusted with sucrose to 305-320 mOsm.

Drug application and preparation. For local drug application to a cell, a perfusion pipette with a large tip opening $(30-50 \mu \mathrm{m})$ was positioned close to the cell. The bath volume was $1.0-1.3 \mathrm{ml}$, and $3 \mathrm{ml}$ of solution could be flushed through the system in about $1 \mathrm{~min}$. As indicated by the disappearance of $\mathrm{Na}^{+}$current when perfused with a solution containing TTX or the block of $\mathrm{Ba}^{2+}$ current by $\mathrm{Cd}^{2+}$, exchange of the solution near the cell studied began $8 \mathrm{sec}$ after solution change and was complete within $30 \mathrm{sec}$. All experiments were performed at room temperature $\left(22-25^{\circ} \mathrm{C}\right)$.

The PKC inhibitor PKC19-36 and the peptide dynorphin A were dissolved in $0.1 \mathrm{~m}$ acetic acid and stored at $-70^{\circ} \mathrm{C}$ for up to 2 months. Aliquots were diluted into the standard internal solution immediately prior to use. In order to minimize structural changes of the PKC activators, which might account for previous inability to depress $\mathrm{Ca}^{2+}$ current (Hockberger et al., 1989), certain precautions were taken. Lipids received from Avanti Polar Lipids or Calbiochem were dissolved in HPLC-grade chloroform and stored under argon in solvent-cleaned tubes at $-70^{\circ} \mathrm{C}$ for up to 2 months. Solutions prepared for application to F11B9 cells were aliquoted just prior to use, dried under argon, reconstituted in dimethylsulfoxide (DMSO) or ethanol, mixed with the standard external or internal pipette solution, and sonicated for $30 \mathrm{sec}$ at $4^{\circ} \mathrm{C}$. Solutions were then used at room temperature for not longer than $6 \mathrm{hr}$. Application of lipids was always preceeded by bath perfusion with the appropriatc final concentration of the vehicle. Likewise, recordings performed with internal application of 1,2-dioctanoylglycerol (diC8) were compared to control recordings performed with the appropriate final dilution of ethanol in the pipette solution. When the hydrophobic diacylglycerol analogs were used, the perfusion chamber, solution changing apparatus, and perfusion tubing were washed with 10 volume changes of absolute ethanol between every cell.

Diacylglycerol release by exposure to bradykinin. For biochemical experiments, F11-B9 cells (passage 2-15) were seeded at a 1:10 dilution into 6-well $\left(10 \mathrm{~cm}^{2}\right)$ plastic culture plates and grown 5-6 d until about $90 \%$ confluent. Cells were then incubated with $3.3 \mu \mathrm{Ci}{ }^{3} \mathrm{H}$-arachidonic acid in $1 \mathrm{ml}$ of growth or differentiation medium for 18-24 hr to label the endogenous lipid pool. After the labeling period, culture plates were transferred to a $37^{\circ} \mathrm{C}$ water bath for the biochemical experiments. In cach cxpcriment, frcshly made buffers and dilutions of bradykinin were made, and duplicate or triplicate samples were used for each condition tested. Unincorporated isotope was removed from the F11-B9 cultures by washing the culture wells twice with $1 \mathrm{ml}$ of either Hank's balanced salt solution or Eagle's minimal essential medium. Both solutions were serum free, contained 20 mM HEPES, and were adjusted with $\mathrm{NaOH}$ to $\mathrm{pH} 7.3-7.4$ at $24^{\circ} \mathrm{C}$.

Biochemical experiments were designed to mimic as closely as possible the physiological experiments and were therefore performed in an external solution containing $30 \mathrm{mM} \mathrm{BaCl}_{2}$. Some experiments were performed in the same external solution used for the electrophysiological experiments $(n=3)$, and some were performed in an external solution in which $100 \mathrm{~mm}$ choline chloride replaced Cs and TEA Cl $(\mathrm{pH}, 7.3-$ 7.35 with $\mathrm{NaOH} ; n=6$ ). The production of diacylglycerol was not significantly different for BK (100 nM, 20-sec exposure) applied in the external solution with or without the $\mathrm{K}^{+}$channel blockers Cs and TEA (2-tailed $t$ test). Thus, biochemical data obtained using either external solution are considered together.

Cells were exposed to the $30 \mathrm{~mm} \mathrm{Ba}{ }^{2+}$ solution (control) or bradykinin dissolved in the $30 \mathrm{mM} \mathrm{Ba}^{2+}$ solution at concentrations ranging from 1 nм to $10 \mu \mathrm{M}$ for time intervals from 5 to $120 \mathrm{sec}$. Bradykinin exposure was terminated by neutral lipid extraction in $2.8 \mathrm{ml}$ of ice-cold chloroform:methanol (1:2). The entire volume of chloroform:methanol and the $\mathrm{Ba}^{2+}$ solution in each well were removed to individual glass vials. Extracted lipids were analyzed by the method previously described by DeGeorge et al. (1986). In brief, $0.9 \mathrm{ml}$ chloroform was added to each tube, the tubes were vortexed and stored at $-20^{\circ} \mathrm{C}$ for $18-36 \mathrm{hr}$. Organic and aqueous phases of the extracts were clarified by centrifugation, and the aqueous phase was removed and discarded. The organic phase was concentrated under nitrogen, during which each tube was washed twice with an additional $0.5 \mathrm{ml}$ chloroform. The extracts were then dried and resuspended in 50-60 $\mu \mathrm{l}$ chloroform.

The entire volume of each extract was spotted on a single lane on a heat-activated LK6D silica G plate. The major lipid classes (phospholipids, phosphatidic acid, triglycerides, diglycerides, monoacylglycerides, arachidonic acid, and arachidonic acid metabolites) were resolved 
by development in a solvent system comprised of the upper phase of a mixture of ethyl acetate, isooctane, acetic acid, and water (93:47:20: 100 ). Chromatography tanks were lined with filter paper and equilibrated for $1 \mathrm{hr}$ prior to development. Developed plates were air dried for 10 min, sprayed lightly with 2 coats of En ${ }^{3}$ hance, covered with Saran wrap, and placed in light-tight envelopes together with Kodak XomatAR5 $x$-ray film for $6-7 \mathrm{~d}$ at $-70^{\circ} \mathrm{C}$. Films were then developed, and the autoradiogram was used to locate radiolabeled lipids on the thinlayer chromatography (TLC) plate. The radiolabeled diacylglycerol spot was well separated from other spots and comigrated with unsaturated diacylglycerol standards (C18:1 or C18:2) as determined by visualization with iodine vapor. In 4 experiments, the ratio $\left(R_{f}\right)$ of the migration distance of the diacylglycerol standard to the migration distance of the solvent front was $0.80 \pm 0.01$, whereas authentic arachidonic acid migrated with an $R_{f}$ value of $0.71 \pm 0.01$. Other radioactive spots were identified based on the migration pattern previously described for this system using extracts prepared from rat DRG neurons (Gammon et al., 1989). Regions of the TLC plate corresponding to spots on the $x$-ray film were individually scraped and transferred to separate scintillation vials. Regions without noticeable spots were also scraped into scintillation vials so that the entire extract was accounted for. Distilled water $(200 \mu \mathrm{l})$ and scintillation cocktail $(5 \mathrm{ml})$ were added to each vial. Scintillation vials were then vortexed, left overnight at room temperature, vortexed again, and counted by liquid scintillation spectrometry using a Packard Tri-Carb $460 \mathrm{CD}$ liquid scintillation system.

Materials. Ham's F-12 media was from GIBCO (Grand Island, NY), and FCS was from Hazelton (Lenexa, KS). HAT was from Flow Laboratories (McLean, VA). All other tissue culture reagents were from Sigma (St. Louis, MO). Bradykinin, dynorphin A (porcinc), and naloxone were purchased from Peninsula Peptides (Belmont, CA) or Sigma. N51A glass for patch pipettes was from Drummond Scientific (Broomall, PA). TTX was from Sigma or Calbiochem (San Diego, CA). GTP was from Boehringer Mannheim Biochemicals (Indianapolis, IN). All salts were of the highest purity available and were purchased from either Alfa (Danvers, MA) or Aldrich (Milwaukee, WI). ${ }^{3} \mathrm{H}$-arachidonic acid (83.6 Ci/mM) and $\mathrm{En}^{3}$ hance were obtained from New England Nuclear Products (Boston, MA), and unlabeled arachidonic acid was from Sigma. Silica gel LK6D thin-layer chromatography plates were purchased from Whatman Ltd. (Maidston, UK). All organic solvents were purchased from Fisher or Mallinckrodt and were HPLC grade. Authentic diacylglycerol standards and 1-oleoyl-2-acetylglycerol (OAG) were from Avanti Polar Lipids (Birmingham, AL) or Calbiochem. 1,2-Dioctanoylglyccrol (diC8) and cthylene glycol dioctanoatc (EGD) were from Molecular Probes (Eugene, OR). The pseudosubstrate inhibitor of PKC (PKC19-36) was from Auspep (Melbourne, Australia). Staurosporine was from Calbiochem.

\section{Results}

Bradykinin inhibits barium current in the F11-B9 subclone

In 25 of 29 cells recorded with the standard internal pipette solution, BK (100 nM) depressed the sustained $\mathrm{Ba}^{2+}$ current by $29 \pm 2.0 \%$ (mean \pm SEM; $n=25$; Fig. $1 B$ ). In contrast to the block of sustained current by $100 \mathrm{nM} \mathrm{BK}$, the transient current was inhibited by only $8.4 \pm 2.5 \%(n=21$; Fig. $1 A)$ in cells expressing both transient and sustained currents. Four F11-B9 cells were considered nonresponders by the criterion that less than $10 \%$ of the sustained $\mathrm{Ba}^{2+}$ current was blocked by $100 \mathrm{nM}$ BK. Thus, $86 \%$ of the F11-B9 cells demonstrated the inhibition of sustained current by BK.

The degree and concentration dependence of inhibition by $\mathrm{BK}$ of transient and sustained $\mathrm{Ba}^{2+}$ currents are compared in Figure 1. BK always blocked a larger fraction of the sustained current than transient current. The $\mathrm{IC}_{50}$ for $\mathrm{BK}$ block of both currents was about $30 \mathrm{nM}$ (Fig. 1D). The onsct of block by BK occurred within $5 \mathrm{sec}$ after applying BK by pressure ejection in a perfusion system that gave complete block of $\mathrm{Ba}^{2+}$ current by $100 \mu \mathrm{M} \mathrm{Cd}{ }^{2+}$ within $5 \mathrm{sec}(n=3$ cells $)$. All other experiments used a slower application of extracellularly applied drugs through a large pipette positioned close to the cell. Each application of BK was not longer than $1 \mathrm{~min}$ because maximal block was achicved in less than $1 \mathrm{~min}$ (usually $25-35 \mathrm{sec}$ ), and after this exposure time, inhibition of $\mathrm{Ba}^{2+}$ currents could be reversed by reperfusion with the control external solution (Fig. $1 A, B$ ). In 3 cells ( $12 \%$ of the responders), the inhibition of $\mathrm{Ba}^{2+}$ current during the continued presence of $100 \mathrm{~nm}$ BK appeared to fade over the course of a 1-min application, suggesting desensitization of the response. In $88 \%$ of the cells that responded to the first application of BK, up to 2 additional applications of BK, separated by at least 2 min during a 15-25-min recording, were effective in producing inhibition of the sustained current. BK inhibition of $\mathrm{Ba}^{2+}$ currents was not associated with a marked change in the current kinetics or a shift in the current-voltage relationships for the sustained (Fig. 1B,C) or transient (Fig. 1A) currents $(n=5$ cells examined over the voltage range of -60 to +40 or $+50 \mathrm{mV}$ ). The possible voltage dependence of the action of BK was not studied at larger test depolarizations (cf. Bean, 1989). All data that follow focus on the inhibition of sustained $\mathrm{Ba}^{2+}$ current.

In contrast to a previous report on DRG neurons (Burgess et al., 1989), BK application to F11-B9 cells was not accompanied by a consistent, substantial change in the holding current at the holding potential of $-70 \mathrm{mV}$. Rarely, a small inward current (up to $10 \mathrm{pA}$ ) accompanied the application of $\mathrm{BK}$, but this effect did not recover following the removal of BK, and the small current could also be produced occasionally by perfusion with control solutions, suggesting that it was simply a perfusion artifact. The BK-induced current in DRG neurons is reported to be carried primarily by $\mathrm{Na}^{+}$(Burgess et al., 1989) and thus would not be expressed under the ionic conditions used here for recording $\mathrm{Ba}^{2+}$ currents. Likewise, $\mathrm{BK}$ application to the F11-B9 cells did not activate an outward current at the holding potential of $-70 \mathrm{mV}$. In the NG108-15 cell line, BK increases a Ca ${ }^{2+}$ activated $\mathrm{K}^{+}$conductance (Brown and Higashida, 1988). The expression of such a current, however, would not be expected under the ionic conditions used here in which $\mathrm{K}^{+}$currents were suppressed by a combination of internal and external $\mathrm{Cs}^{+}$and TEA.

\section{Effects of activators and inhibitors of protein kinase $\mathrm{C}$ Activators: $O A G$ and diC8}

Figure 2 compares in the same cell the inhibition of sustained $\mathrm{Ba}^{2+}$ current produced by maximal concentrations of BK (100 nM) and OAG (5 $\mu \mathrm{M})$, a DAG analog that activates PKC (Nishizuka, 1984; Ebeling et al., 1985). When tested on the same cell, maximal concentrations of $\mathrm{OAG}$ reduced the sustained $\mathrm{Ba}^{2+}$ current to nearly the same level as that produced by $100 \mathrm{nM}$ BK (Fig. 2A,C). Moreover, in the continued presence of $5 \mu \mathrm{M}$ OAG, $100 \mathrm{nM}$ BK produced no further block of the sustained current ( $n=3$ cells), indicating that the effects of the 2 drugs were not additive. Effects of extracellularly applied PKC activators were measured after a 2-min exposure. This exposure time was sufficiently long to produce maximal block by a particular concentration of OAG and also allowed partial reversibility of the block upon returning to perfusion with control solutions (Figs. $2 A, 3 A$ ). Incomplete reversibility of the effects of the PKC activators may be due to their hydrophobic nature. In some experiments $(n=4$ cells), OAG $(5 \mu \mathrm{M})$ was applied for up to $5 \mathrm{~min}$ and produced no further change in any component of the whole-cell $\mathrm{Ba}^{2+}$ current in F11-B9 cells. Depression of sustained $\mathrm{Ba}^{2+}$ current in F11-B9 cells by OAG was not accompanied by an obvious change in kinetics of the whole-cell $\mathrm{Ba}^{2+}$ current (Fig. $2 A$ ) or the current-voltage relationship for the sus- 

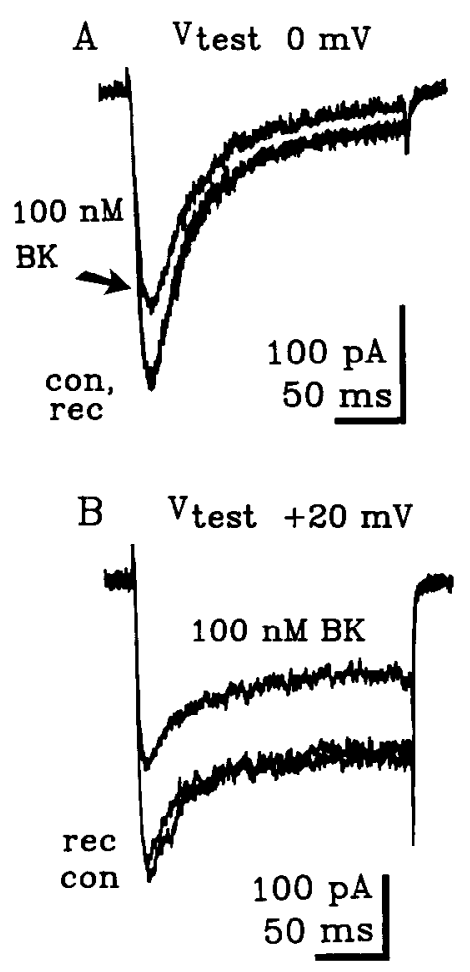

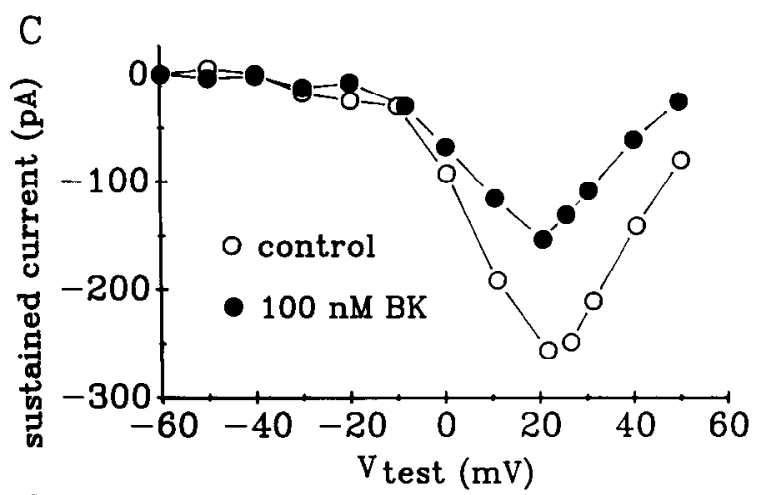

D

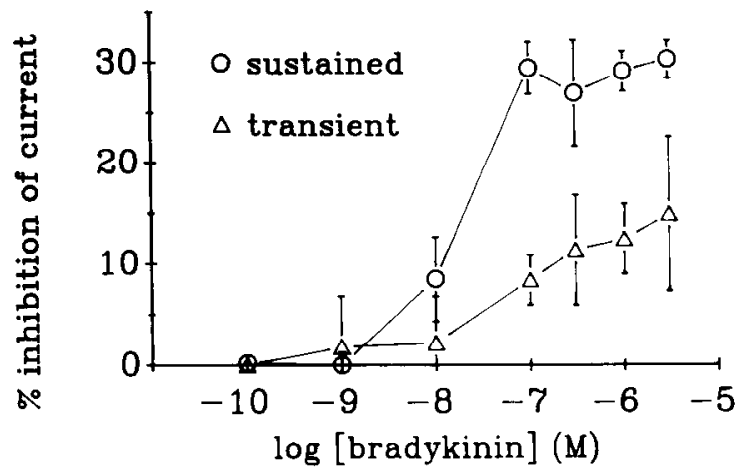

Figure 1. $\mathrm{BK}$ block of $\mathrm{Ba}^{2+}$ currents in F11-B9 cells. $A$ and $B$, Current traces recorded from the same cell. Inward currents were elicited from a holding potential of $70 \mathrm{mV}$ with test depolarizations $\left(\mathrm{V}_{\text {rest }}\right)$ to $0 \mathrm{mV}(A)$ or +20 $\mathrm{mV}(B)$ and represent control $\mathrm{Ba}^{2+}$ currents (con), partial block of the currents during exposure to $100 \mathrm{nM} \mathrm{BK}$, and recovery $(\mathrm{rec})$ of the current $2 \mathrm{~min}$ after beginning the washout of BK. BK blocked $11 \%$ of the transient $(A)$ and $55 \%$ of the sustained current $(B)$ in this cell. $C$, Current-voltage curve for the sustained current (different cell) recorded in control solution (open circles) and after maximum block by $100 \mathrm{~nm}$ BK (solid circles). D, Dose-response relationships for inhibition of transient (triangles) and sustained (circles) currents by BK. All currents were elicited from a holding potential of $-70 \mathrm{mV}$, with depolarizations to $0 \mathrm{mV}$ (transient) or $+20 \mathrm{mV}$ (sustained). Each data point is the mean \pm SEM for $3-6$ cells, except for $100 \mathrm{nM} \mathrm{BK}$, for which $n=21$. A maximum of 3 concentrations of $\mathrm{BK}$ were tested on an individual cell. tained current (Fig. $2 C ; n=5$ cells examined over the voltage range of -60 to +40 or $+50 \mathrm{mV}$ ) as reported by others in DRG neurons (Rane and Dunlap, 1986; Marchetti and Brown, 1988). On individual cells, multiple applications of OAG (up to 5 tested) were effective. The sustained $\mathrm{Ba}^{2+}$ current of all 6 cells tested was inhibited by 50-500 nM OAG. Maximum block occurred with about $500 \mathrm{~nm}$ OAG, which reduced the sustained current by $29 \pm 6.9 \%(n=4)$. Application of 5 or $50 \mu \mathrm{M}$ OAG usually produced no further block (see Fig. 5).

Figurc 3, $A$ and $B$, compares the inhibition of sustained $\mathrm{Ba}^{2+}$ current produced by diC8, a stable DAG analog that activates $\mathrm{PKC}$, and $\mathrm{EGD}$, an analog of diC8 that is reported not to activate

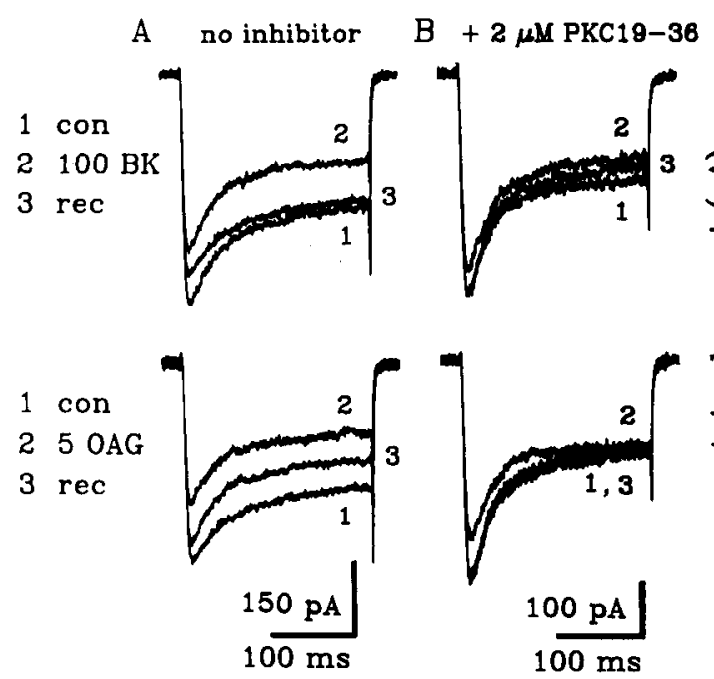

C no inhibitor

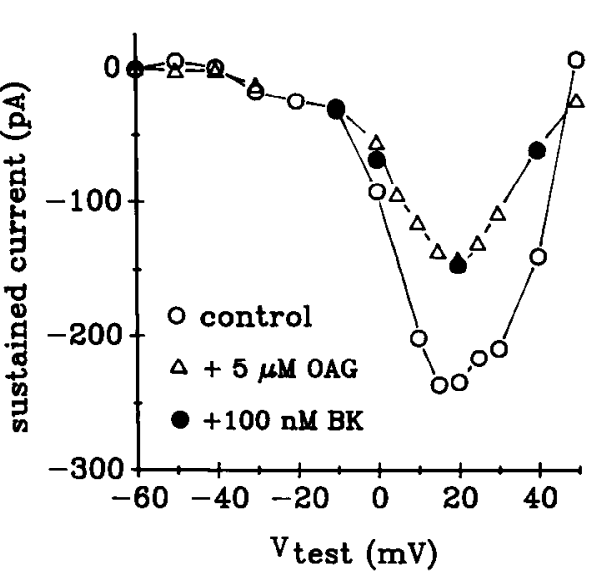

Figure 2. Similarity of the inhibition of sustained $\mathrm{Ba}^{2+}$ current by OAG and $\mathrm{BK}$. $\mathrm{Ba}^{2+}$ currents in $A$ and $B$ were elicited by depolarizations to $+20 \mathrm{mV}$ from a holding potential of $-70 \mathrm{mV}$ and represent $\mathrm{Ba}^{2+}$ currents recorded with $(A)$ the control pipette solution or $(B)$ a pipette solution containing the protein kinase $\mathrm{C}$ inhibitor PKC19-36 $(2 \mu \mathrm{M})$. Currents were recorded before $(1)$ and during $(2)$ the maximum inhibition produced by 1 min exposure to $100 \mathrm{nM}$ BK or 2 min exposure to $5 \mu \mathrm{M}$ OAG and during partial recoveries (3) 2 min after the washout of BK or OAG. Both sets of traces in $A$ are from the same cell, and traces in $B$ are from the same cell. $C$, Current-voltage relationship for the sustained current (same cell as in $A$ ) recorded with the control external solution (open circles) or following the maximum block produced by $5 \mu \mathrm{M}$ OAG (open triangles). For comparison, 4 data points for the sustained current recorded after maximum block by 100 nм BK are shown (solid circles). See Figure 1 for abbreviations. 

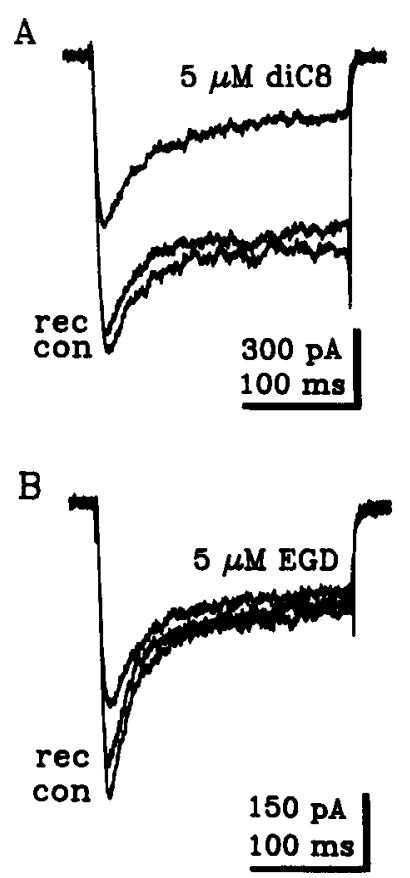
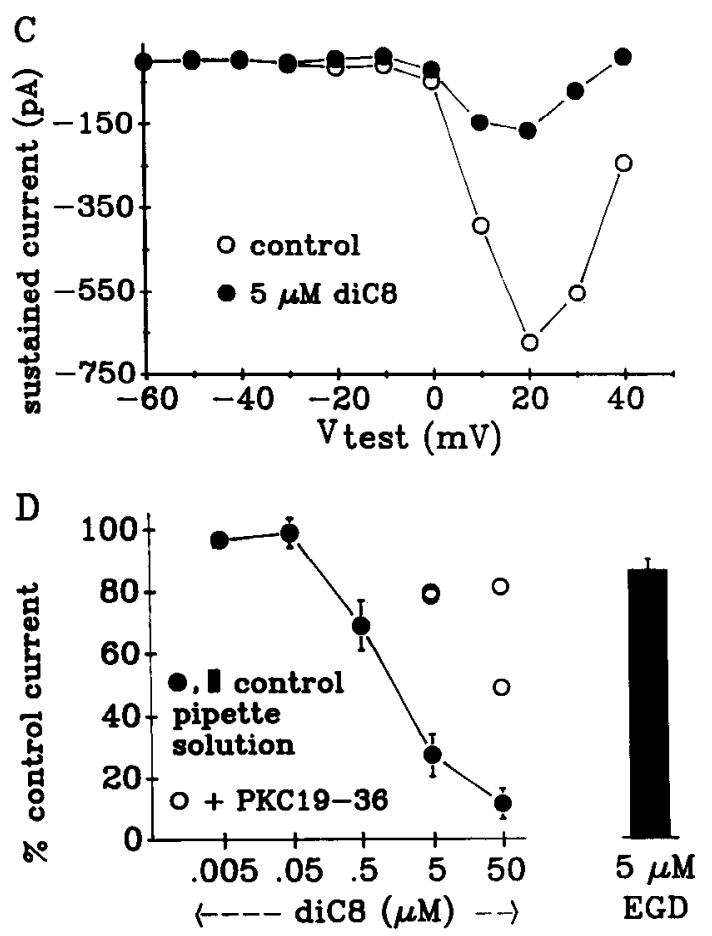

Figure 3. Inhibition of sustained $\mathrm{Ba}^{2+}$ current by diC8. $A$ and $B$, Current traces recorded from 2 different F11-B9 cells. Currents were elicited from a holding potential of $-70 \mathrm{mV}$ with test depolarizations $\left(\mathrm{V}_{\text {test }}\right)$ to $+20 \mathrm{mV}$ and represent control currents (con), partial block of the currents during a 2-min exposure to the PKC activator diC8 $(5 \mu \mathrm{M} ; A)$ or the inactive analog EGD $(5 \mu \mathrm{M} ; B)$, and recovery (rec) of the current 2 min after beginning the washout of the drug. Both recordings were made with a control pipette solution (no PKC inhibitor). $C$, Current-voltage curves for the sustained current (same cell as in $A$ ) recorded in control external solution (open circles) and after block by $5 \mu \mathrm{M}$ diC8 (solid circles). $D$, Comparison of the inhibition of sustained current by diC8 and EGD. For diC8, each data point is the mean \pm SEM for 4-7 cells. For EGD, the solid bar represents the mean \pm SEM for block of sustained current in 8 cells in the absence of PKC inhibitor. The inhibition of sustained current produced by $5 \mu \mathrm{M}$ diC 8 was significantly greater than that produced by $5 \mu \mathrm{M}$ EGD ( $p<0.001,2$-tailed $t$ test). For comparison, the degree of block by 5 or $50 \mu \mathrm{M}$ diC8, recorded with $2 \mu \mathrm{M}$ PKC19-36 inside the pipette solution, is shown for 4 different cells (open circles).

PKC (Bishop and Bell, 1986; Ganong et al., 1986). In the presence of $5 \mu \mathrm{M} \mathrm{diC} 8$, the sustained current was markedly reduced (Fig. $3 A$ ), while the same concentration of EGD was much less effective (Fig. $3 B$ ). EGD at a concentration of $5 \mu \mathrm{M}$ produced $14 \pm 3.8 \%$ block $(n=8)$ of sustained current (Fig. $3 D$, solid bar), whereas an equal concentration of the active analog $\mathrm{diC} 8$ produced $71 \pm 6.8 \%$ block ( $n=11$ ) of sustained current. Concentration-response curves for the block of sustained $\mathrm{Ba}^{2+}$ current by diC8 (Fig. $3 D$ ) indicate that maximum block occurred with about $50 \mu \mathrm{M} \mathrm{diC} 8$, which reduced the sustained current by about $90 \%$. Inhibition of sustained current by diC8 was partially or completely reversible upon returning to perfusion with control solutions (Fig. $3 A$ ). The sustained $\mathrm{Ba}^{2+}$ current of every F11-B9 cell tested was inhibited by at least 500 nm diC8. Depression of sustained current by $\mathrm{diC} 8$ was not accompanied by a marked change in the current-voltage relationship (Fig. $3 C$; $n=3$ cells examined over the voltage range of -60 to +40 or $+50 \mathrm{mV}$ ). Similar to OAG, multiple applications of diC8 were effective in producing block of the sustained current.

Because external application of 5-50 $\mu \mathrm{M}$ diC8 blocked about $70-90 \%$ of the sustained $\mathrm{Ba}^{2+}$ current in F11-B9 cells, it was of interest to determine whether internal application of the highly lipid-soluble diC8 would also block sustained current. The inclusion of $5 \mu \mathrm{M} \mathrm{diC8}$ in the pipette solution blocked $90-100 \%$ of sustained current in each of 3 cells tested in which the uncompensated series resistance was 3-4 M $\Omega$ (Fig. $4 B$, solid circle). The block produced by internally applied diC 8 began $7-10.5$ min after rupture of the patch and was complete in 12-18 $\mathrm{min}$ (Fig. $4 A, B$ ). Our observation that maximal block by external application of diC 8 could be achieved in 90 sec suggests a slow diffusion of the lipid out of the pipette solution. In one cell, internally applied diC 8 produced only a $20 \%$ block of the sustained current after $18 \mathrm{~min}$, but in this recording the series resistance had climbed to over $20 \mathrm{M} \Omega$ within 10 min, suggesting that the pipette was clogged and access to the added diC 8 was likely impaired. In contrast, in each of 17 control recordings using the standard pipette solution plus $0.1 \%$ ethanol or $2 \mu \mathrm{M}$ dynorphin, sustained current amplitude was relatively stable within the first $18 \mathrm{~min}$ after establishing the whole-cell recording (Fig. $4 B$, open square). In these control experiments, no drugs were applied externally for the duration of the recording. Moreover, in recordings from $>75 \mathrm{~F} 11-\mathrm{B} 9$ cells used in other experiments, rapid and complete rundown of the sustained current was never found under the ionic conditions employed here. In some control experiments, a small degree of rundown of sustained current (approximately 30\% reduction after 15-20 min) was observed. Thus, OAG was not tested in the pipette solution because the maximal effect expected (about 30\% inhibition) would have been difficult to distinguish from a small degree of rundown that occurs in some cells.

\section{Inhibitors: PKC19-36 and staurosporine}

In some experiments, a PKC inhibitor was added to the pipette solution, and cells were held for 7-11 min after rupture of the 

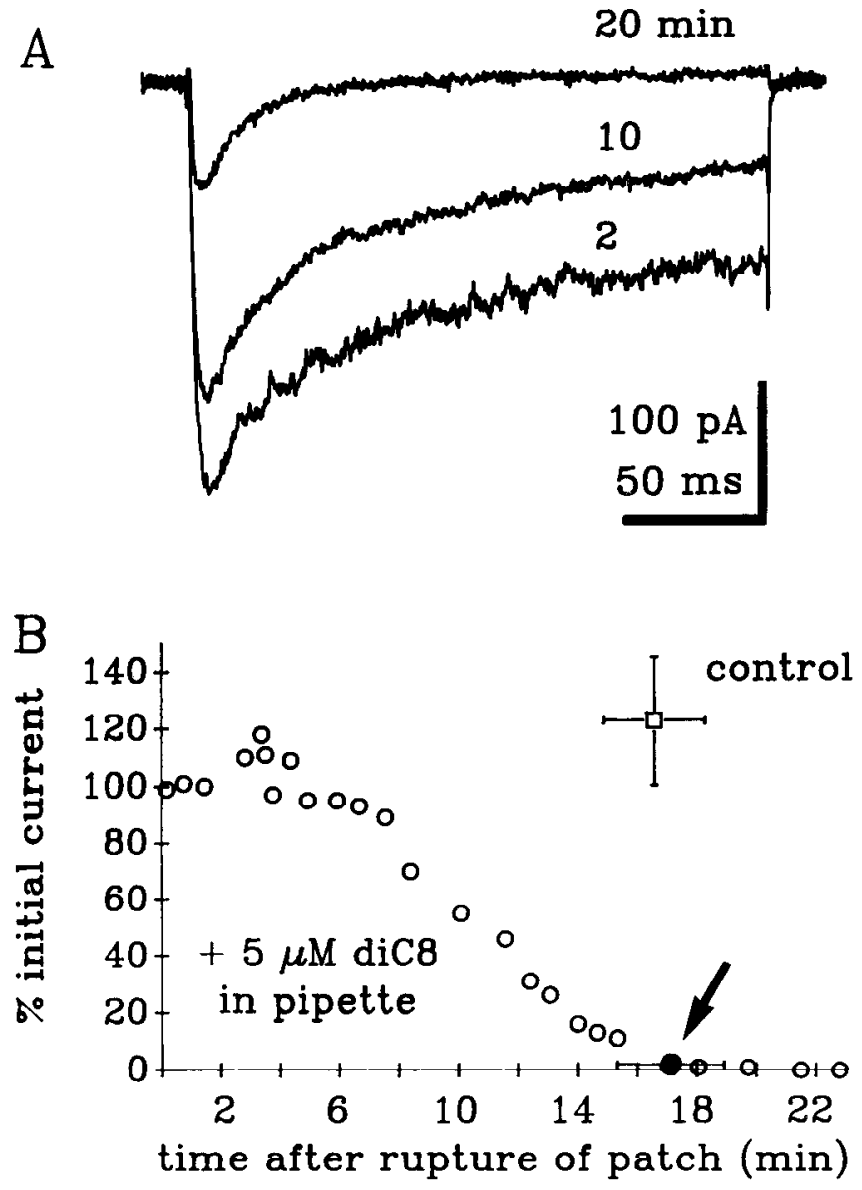

Figure 4. Inclusion of $\mathrm{diC} 8$ in the pipette solution promotes "rundown" of the sustained $\mathrm{Ba}^{2+}$ current. $A, \mathrm{Ba}^{2+}$ currents recorded at the indicated times $(2,10$, or $20 \mathrm{~min})$ after rupture of the membrane patch to establish the whole-cell recording with a pipette solution containing $5 \mu \mathrm{M}$ diC8. All currents were elicited from $-70 \mathrm{mV}$, with depolarizations to $+20 \mathrm{mV}$. $B$, Data from the same cell expressed as the percent of the initial sustained current that remained during a 23-min recording in the presence of internally applied diC8 (open circles). The solid circle (arrow) represents the maximum block produced by internally applied diC 8 (mean $\pm \mathrm{SEM} ; n=3$ ). The open square represents the fraction of current that remained during control recordings performed (in the absence of diC8) with $0.1 \%$ ethanol or $2 \mu \mathrm{M}$ dynorphin A in the pipette solution (mean $\pm \mathrm{SEM} ; n=17$ ). For these control experiments, cells were not exposed to other drugs.

patch to allow the inhibitor to diffuse into the cytoplasm. A specific inhibitor of PKC, the pseudosubstrate peptide PKC1936 ( $2 \mu \mathrm{M}$; House and Kemp, 1987), reduced the effect of external application of 0.005-5 $\mu \mathrm{M}$ OAG (Figs. $2 B, 5$ ) though a higher concentration of OAG could overcome the block of sustained current in 2 of 4 cells. PKC19-36 reduced the effects of maximally effective concentrations of BK $(n=5)$ and OAG $(n=9)$ by approximately the same extent $(61 \%$ and $58 \%$, respectively; Figs. $2 B, 5$; cf. solid circle and solid bar in Fig. 5). The effects of internally applied PKC19-36 were also tested on the inhibition produced by diC 8 in 4 F11-B9 cells. In each cell, the inhibition of sustained current produced by diC 8 was less in the presence of inhibitor than the mean response in the absence of inhibitor (Fig. 3D; cf. open circles to solid circles for 5 and 50 $\mu \mathrm{M} \mathrm{diC8)}$. When the effects of 5 or $50 \mu \mathrm{M}$ diC8 on the 4 cells recorded in the presence of inhibitor are considered together, $\mathrm{diC} 8$ was still able to reduce an average of $28 \%$ of the sustained

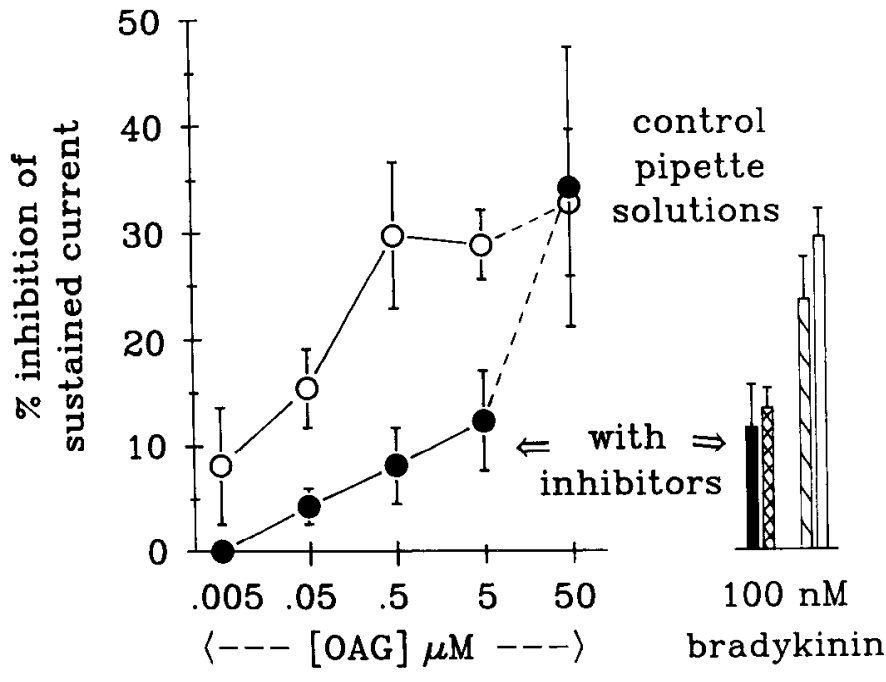

Figure 5. Inhibitors of PKC reduce the inhibition of sustained $\mathrm{Ba}^{2+}$ current produced by OAG or BK. Dose-response relationships are shown to the left for the inhibition of sustained current produced by OAG in cells recorded with the control pipette solution (open circles) or pipette solution containing the PKC inhibitor $2 \mu \mathrm{M}$ PKC19-36 (solid circles). Each data point is the mean \pm SEM for 3-10 F11-B9 cells. For comparison, the degree of inhibition of sustained current by $100 \mathrm{nM}$ BK is shown to the right for recordings performed with the control pipette solutions containing either no additions (open bar; $n=25$ ) or $2 \mu \mathrm{M}$ dynorphin A (hatched bar; $n=9$ ). The degree of inhibition produced with dynorphin is not significantly different from that produced in the absence of any additions $(0.05<p<0.1,2$-tailed $t$ test). The degree of inhibition of sustained current is also shown for recordings performed with pipette solutions containing the PKC inhibitors $2 \mu \mathrm{M}$ PKC19-36 (solid bar; $n=5$ ) or $100 \mathrm{~nm}$ staurosporine (cross-hatched bar; $n=6$ ). The effect of $5 \mu \mathrm{M}$ OAG or $100 \mathrm{nM}$ BK was significantly reduced by the PKC inhibitors ( $p<0.01,2$-tailed $t$ test). All bars represent means \pm SEM.

current. In summary, $2 \mu \mathrm{M}$ PKC19-36 reduced but did not abolish the inhibition of $\mathrm{Ba}^{2+}$ current by $2 \mathrm{PKC}$ activators, OAG and $\mathrm{diC} 8$, and by BK itself.

Staurosporine is a potent, nonspecific kinase inhibitor $(\mathrm{Hi}$ daka et al., 1984; Tamaoki et al., 1986) that has been used in a number of electrophysiological studies (cf. Bosma and Hille, 1989; Burgess et al., 1989; Conn et al., 1989). The lipid, dissolved in ethanol, was included in the pipette solution at a concentration of $100 \mathrm{nM}$. In the presence of staurosporine, the average block produced by a single application of $100 \mathrm{nM} \mathrm{BK}$ at 7-11 min was $13 \pm 1.9 \%$ (Fig. 5, cross-hatched bar; $n=6$ ), which is significantly different from the degree of block produced by single applications of $100 \mathrm{nM}$ BK at 7-11 min in control recordings in the absence of staurosporine ( $26 \pm 3.5 \%$ block; $n$ $=9 ; p<0.01,2$-tailed $t$ test). In addition, in 3 cells the effect of staurosporine was measured as the percent inhibition of sustained current produced by a second exposure to $100 \mathrm{nM} \mathrm{BK}$, where the first exposure occurred at $2.5-4.5 \mathrm{~min}$ and the second at 9.5-11 min after establishing the whole-cell recording. In the presence of internally applied staurosporine, a second response to $\mathrm{BK}$ was reduced by $66.7 \pm 4.8 \%$ when compared to the first response to $\mathrm{BK}$ in the same cell.

We performed 3 additional experiments to control for nonspecific effects of the PKC inhibitors or "chance" reduction in the effectiveness of BK and OAG. First, $2 \mu \mathrm{M}$ dynorphin A was used in the pipette solution as a control for nonspecific effects of the pseudosubstrate PKC19-36. These 2 peptides have sim- 

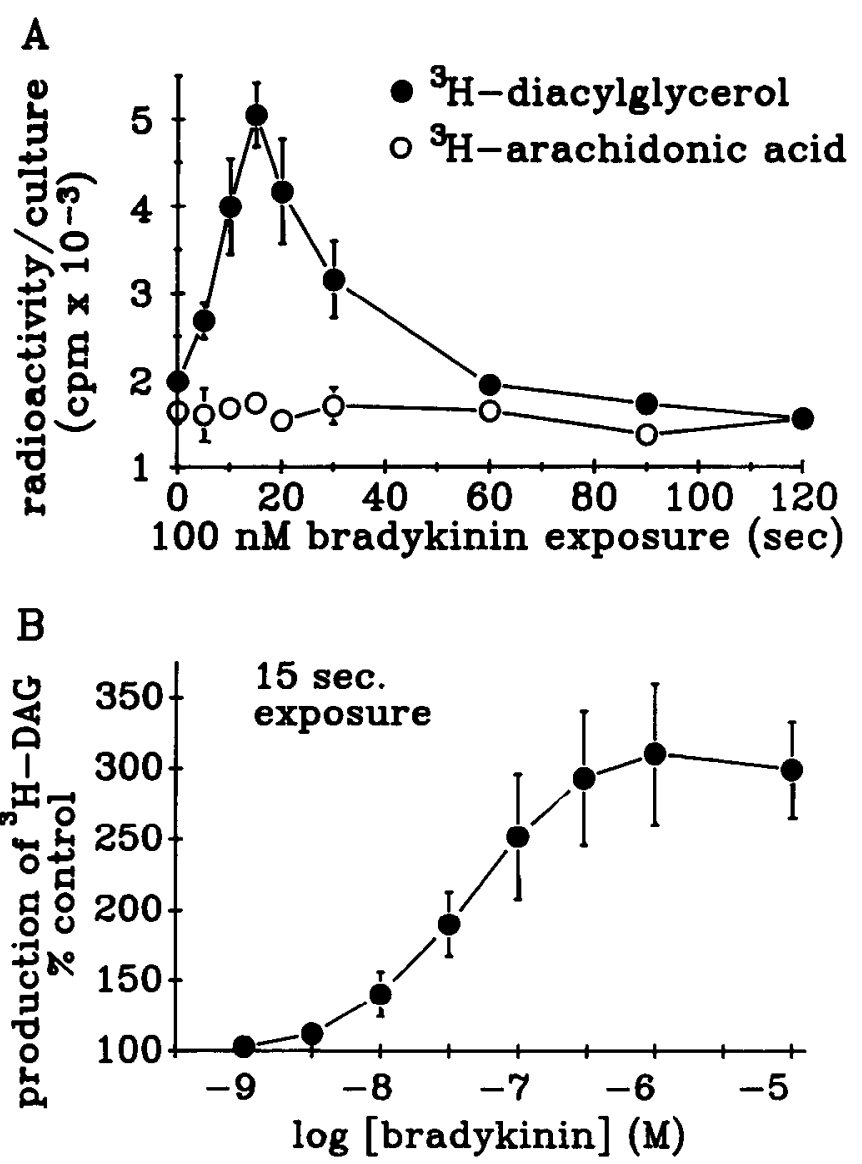

Figure 6. Time course and dose dependence of BK-induced production of DAG. F11-B9 cultures were labeled with ${ }^{3} \mathrm{H}$-arachidonic acid for 18 $24 \mathrm{hr}$, exposed to $\mathrm{BK}$ at $37^{\circ} \mathrm{C}$ in a buffered solution containing $30 \mathrm{~mm}$ $\mathrm{Ba}^{2+}$, and extracted for ${ }^{3} \mathrm{H}$-lipids, as described in Materials and Methods. $A$, Cultures were exposed to $100 \mathrm{nM} \mathrm{BK}$ for the time periods indicated. Data are presented as the amount of radioactivity (in cpm) in the diglyceride spot (solid circles) or the arachidonic acid spot (open circles), where the region of the TLC plate that was scraped was determined by comigration with authentic lipid standards. Control levels of radioactivity were determined after incubation in the buffer solution (minus BK) for 15,20 , or $30 \mathrm{sec}$ and did not differ for these time points $(n=11)$, so these data were considered together and plotted on the y-axis at $t=0$ sec. Each data point is the mean \pm SEM for 3-5 experiments performed in duplicate or triplicate, except for the data points at 60,90 , and 120 $\mathrm{sec}$, which represent the average of 2 experiments performed in duplicate. Cultures contained an average of $499,000 \pm 22,400 \mathrm{cpm}$ in the solvent-extractable lipids $(n=57)$. Similar experiments performed on rat DRG cultures showed comparable results for the production of ${ }^{3} \mathrm{H}$ DAG when cultures were incubated at 25,32 , or $37^{\circ} \mathrm{C}$. $B$, Cultures were incubated with the indicated concentration of $\mathrm{BK}$ for $15 \mathrm{sec}$. Data for ${ }^{3} \mathrm{H}$-DAG production are expressed as percent control, where the control consisted of incubation for $15 \mathrm{sec}$ in the same buffer solution without BK. Each data point is the mean \pm SEM for $3-4$ experiments performed in duplicate. The $\mathrm{EC}_{50}$ for $\mathrm{BK}$-induced production of ${ }^{3} \mathrm{H}-\mathrm{DAG}$ is about $40 \mathrm{~nm}$.

ilar net changes, sizes, and structures, but dynorphin does not contain serine or threonine phosphorylation sites. Experiments with dynorphin $\mathrm{A}$ were performed with the addition of $10 \mu \mathrm{M}$ naloxone to the external solution to prevent activation of opioid receptors, if present. Eight of 9 cells $(87 \%)$ responded to BK in the presence of dynorphin $\mathrm{A}$, similar to the $86 \%$ response rate in the absence of this peptide. After allowing $>7 \mathrm{~min}$ for dynorphin $A$ to diffuse out of the patch pipette, exposure to 100 nM BK demonstrated $25 \pm 4.3 \%$ block of sustained $\mathrm{Ba}^{2+}$ current, not significantly different from the degree of block in the absence of dynorphin (Fig. 5, cf. hatched and open bars). Second, in some experiments, ethanol ( $0.1 \%$ final concentration) was added to the pipette solution as a control for the inclusion of staurosporine. In these experiments, a single application of $100 \mathrm{nM} \mathrm{BK}$ at $8-11$ min blocked $32 \pm 5.6 \%$ of sustained current $(n=3)$. Third, in all experiments in which a PKC inhibitor was used, at least one cell (typically 2-4) was recorded from in the absence of inhibitor in order to demonstrate that, with a particular passage and plating of F11-B9 cells and particular solution of $O A G$, $\mathrm{BK}$, or diC8, the typical block of sustained current could be observed in the absence of the PKC inhibitor.

$\mathrm{Ba}^{2+}$ currents of $\mathrm{F} 11-\mathrm{B} 9$ cells recorded in the presence of internally applied PKC19-36, staurosporine, dynorphin A, or ethanol demonstrated no marked differences in their stability, activation and inactivation profiles, or relative expression of transient and sustained currents, with 1 exception: current-voltage curves for the transient current were shifted by $+10 \mathrm{mV}$ during the exposure to diC8. Amplitudes of the transient and sustained $\mathrm{Ba}^{2+}$ currents were not significantly different (2-tailed $t$ test) for recordings performed in the presence of the PKC inhibitors $(n=14)$ when compared with control F11-B9 cells of the same passages in which the internal solution contained either $2 \mu \mathrm{M}$ dynorphin or $0.1 \%$ ethanol $(n-14)$.

\section{BK stimulates DAG production in F11-B9 cells}

In 9 experiments, the maximal production of ${ }^{3} \mathrm{H}-\mathrm{DAG}$ by exposure to $100 \mathrm{~nm} \mathrm{BK}$ in a $30 \mathrm{~mm} \mathrm{Ba}{ }^{2+}$ external solution was $270 \pm 22 \%$ (mean $\pm \mathrm{SEM}$ ) of control. Accumulation of ${ }^{3} \mathrm{H}$ DAG upon exposure to $100 \mathrm{nM}$ BK (approximate $\mathrm{EC}_{80}$ ) was detected at the earliest time point measured $(5 \mathrm{sec})$ and returned to control levels by $60 \mathrm{sec}$ (Fig. 6A). Over a 2 -min time course, the accumulation of ${ }^{3} \mathrm{H}-\mathrm{DAG}$ occurred in one distinct phase with a peak near $15 \mathrm{sec}$. Interestingly, in the same extracts, F11B9 cells did not liberate appreciable amounts of ${ }^{3} \mathrm{H}$-arachidonic acid upon exposure to $\mathrm{BK}$ (Fig. $6 \mathrm{~A}$ ). The maximal accumulation of arachidonic acid after a 15 - or 20 -sec incubation with 100 nM BK was $112 \pm 9 \%$ of control $(n=9)$. Data points in Figure $6 A$ represent the means \pm SEM for 3-5 separate experiments periormed in duplicate or triplicate, except for the 60-, 90-, and 120 -sec time points, which represent the average of 2 experiments. Data are expressed as radioactivity present in ${ }^{3} \mathrm{H}-\mathrm{DAC}$ or ${ }^{3} \mathrm{H}$-arachidonic acid after exposure to $\mathrm{BK}$ or the external solution alone.

The increase by $\mathrm{BK}$ (15-sec exposure) of ${ }^{3} \mathrm{H}-\mathrm{DAG}$ production was concentration dependent, with a threshold near $3 \mathrm{~nm}$ and maximal accumulation occurring near $1 \mu \mathrm{M}$ (Fig. 6B). Halfmaximal production of DAG occurred at about $40 \mathrm{nM} B K$, similar to the $\mathrm{IC}_{50}$ for $\mathrm{BK}$ block of the $\mathrm{Ba}^{2+}$ currents (Fig. 1D). The range of effective $\mathrm{BK}$ concentrations also approximates those reported for the $\mathrm{BK}$-induced stimulation of $\mathrm{IP}_{3}$ in the parent F-11 cell line (Francel et al., 1987b, 1989). Data points in Figure $6 B$ represent the mean \pm SEM for 3-4 experiments performed in duplicate and are expressed as a percent of the levels of ${ }^{3} \mathrm{H}-\mathrm{DAG}$ found in control extracts from the same expcriment.

\section{Discussion}

Evidence for a role of $P K C$ in the regulation of sustained barium current

Several lines of evidence support the idea that PKC is a likely mediator of the BK-induced reduction of voltage-activated sus- 
tained $\mathrm{Ba}^{2+}$ current in a DRG cell line, F11-B9. We have demonstrated elevation of a radiolabeled pool of DAG which is an endogenous activator of $\mathrm{PKC}$, as well as simulation of the $\mathrm{BK}$ effect by membrane-permeable activators of $\mathrm{PKC}$ and blockade of the $\mathrm{BK}$ reduction of $\mathrm{Ca}^{21}$ channel current by $\mathrm{PKC}$ inhibitors.

One requirement for implicating a second messenger in the regulation of an ion channel is that the properties of agonistinduced formation of second messenger should be similar to the agonist-induced modulation of channel function. Similarity in the concentration dependence of the inhibition of sustained $\mathrm{Ba}^{2+}$ current (Fig. 1D) and accumulation of ${ }^{3} \mathrm{H}-\mathrm{DAG}$ (Fig. 6B) by $\mathrm{BK}$ exposure to Fll-B9 cells is consistent with the hypothesis that these 2 effects are related. It is important to note that ${ }^{3} \mathrm{H}$ DAG production induced by $\mathrm{BK}$ was measured under ionic conditions similar to those used for the physiological recordings of inhibition of $\mathrm{Ba}^{2+}$ current. Furthermore, ${ }^{3} \mathrm{H}-\mathrm{DAG}$ production induced by $\mathrm{BK}$ is rapid enough (Fig. $6 \mathrm{~A}$ ) to account for the inhibition of $\mathrm{Ba}^{2+}$ current, which occurs within a few seconds. While DAG is not the only endogenous activator of PKC (Nishizuka, 1984; Kikkawa and Nishizuka, 1986), all PKC isozymes described thus far require DAG for full activation in vitro (Murakami et al., 1986; Huang et al., 1988; Nishizuka, 1988; Naor et al., 1988).

The ability of DAG analogs OAG and diC8 to inhibit sustained $\mathrm{Ba}^{2+}$ current (Figs. 2, 3) is consistent with a role for $\mathrm{PKC}$ in the inhibition of this current. The effective concentration ranges of $\mathrm{OAG}$ and $\mathrm{diC} 8$ correspond well with concentrations used to activate PKC in cell-free enzymatic assays (Ganong et al., 1986) and concentrations used to modulate ion channel function in other cell types (DeRiemer et al., 1985; Rane and Dunlap, 1986; Hammond et al., 1987; Doerner et al., 1988; Marchetti and Brown, 1988; Vivaudou et al., 1988; Bosma and Hille, 1989). EGD, a structural analog of diC8 that does not activate PKC (Bishop and Bell, 1986; Ganong et al., 1986), was less effective as an inhibitor of sustained $\mathrm{Ba}^{2+}$ current in F11B9 cells (Fig. 3B,D). Additional evidence for a role for $\mathrm{PKC}$ is the ability of inhibitors of PKC to reduce the effects of activators of PKC and $\mathrm{BK}$ itself on the sustained $\mathrm{Ba}^{2+}$ current. The PKC inhibitor PKC 19-36 (2 $\mu \mathrm{M}$ in pipette) reduced the effects of maximal concentrations of OAG and $\mathrm{BK}$ by the same extent, nearly $60 \%$ (Fig. 5). The nonspecific kinase inhibitor staurosporine (100 $\mathrm{nm}$ in pipette) also reduced the response to $100 \mathrm{nM}$ BK by about $55 \%$ (Fig. 5).

The evidence that $\mathrm{PKC}$ regulates the sustained $\mathrm{Ba}^{2+}$ current in F11-B9 cells is thus convergent, but it is circumstantial. The strength of these interpretations depends on the specificity of the pharmacological tools used to investigate this pathway, namely, OAG, diC8, EGD, and the inhibitors PKC19-36 and staurosporine. Although the specificity of these drugs has been characterized in cell-free enzymatic assays (Ebeling et al., 1985; Bishop and Bell, 1986; Ganong et al., 1986; House and Kemp, 1987), their specific actions are difficult to determine under more physiological conditions. In addition, it is not known whether the PKC activators or the inhibitors preferentially act on certain PKC isozymes. Peptide inhibitors of PKC, such as PKC19-31 and PKC19-36, have been used by only 2 other groups performing whole-cell patch-clamp experiments. In both cases (Bosma and Hille, 1989; Rane et al., 1989), the peptide inhibitor reduced the effect of an exogenous activator of PKC (OAG or phorbol ester) on an ionic current. In comparison with lipid inhibitors of PKC, such as staurosporine and sphingosine (e.g., Doerner et al., 1988; Conn et al., 1989), peptide inhibitors have been recently introduced, and there is even less information available on their actions unrelated to PKC. Dynorphin A has a similar amino acid composition, molecular weight, and net charge as PKC19-36, so we used this peptide as a control for nonspecific effects of PKC19-36 due, for example, to its highly basic nature. Dynorphin A applied to F11-B9 cells in the pipette solution $(2 \mu \mathrm{M})$ did not inhibit the effect of $100 \mathrm{nM}$ BK on the current (Fig. 5) and did not alter any properties of the sustained $\mathrm{Ba}^{2+}$ current in F11-B9 cells.

A major limitation of both the electrophysiological experiments performed on single chick DRG neurons (Rane et al., 1989) and single F1 1-B9 cells is the inability to measure changes in PKC activity in the very cell exposed to the activator or inhibitor of PKC. More compclling evidence for a role for PKC in the $\mathrm{BK}$-mediated reduction of sustained $\mathrm{Ba}^{2+}$ current in $\mathrm{F} 11$ $B 9$ cells would require information about the subspecies of $\mathrm{PKC}$ present in F11-B9 cells and the specific activation characteristics of these isozymes, followed by reconstitution of the components of the transduction pathway into lipid bilayers.

\section{Comparison of the effects of $D A G$ analogs}

The effect of diC8 on sustained $\mathrm{Ba}^{2+}$ current in $\mathrm{F} 11-\mathrm{B} 9$ cells was clearly different from that produced by both OAG and BK. Most of the sustained current (range, 74-98\%) could be blocked by 5-50 $\mu \mathrm{M}$ diC8, whereas both OAG and BK produced a maximum of about $30 \%$ reduction. This indicates that the 2 DAG analogs differ in either their efficacy or their specificity of stimulation of PKC. Differences in efficacy might be achieved by differences in the rate or extent of degradation in the cytoplasm, solubility in the membrane, access to $\mathrm{PKC}$, or preferential activation of certain isozymes of PKC. It is also possible that $\mathrm{OAG}$ and $\mathrm{BK}$ activate (indirectly) protein phosphatases but that diC8 does not. These possibilities were not addressed in our study.

Unlike a number of other membrane-permeable activators of PKC, high concentrations of $\operatorname{diC} 8(>12.5 \mu \mathrm{M})$ are reported to induce cytosolic acidification and release of intracellular $\mathrm{Ca}^{2+}$ in lymphocytes (Ebanks et al., 1989). These effects of diC8 were not blocked by chronic exposure to phorbol ester (Ebanks et al., 1989), which was expected to downregulate PKC. Because of the high $\mathrm{H}^{+}$and $\mathrm{Ca}^{2+}$, buffering capacity of the pipette solution used in the present study, it is not expected that diC8 would cause acidification or release of intracellular $\mathrm{Ca}^{2+}$, but such effects cannot be ruled out by our data.

\section{Modulation of different channels by BK may occur through a common PKC pathway}

As discussed previously, $\mathrm{BK}$ is reported to block whole-cell $\mathrm{Ca}^{2+}$ currents in cultured rat DRG neurons (Ewald et al., 1989; but see Dolphin et al., 1989), as well as in F11-B9 cells. In currentclamp recordings, BK depolarizes a subpopulation of DRG neurons (Baccaglini and Hogan, 1983; McGehee and Oxford, 1988, 1989; Burgess et al., 1989). This depolarization is likely caused by the opening of a nonselective monovalent cation channel, as recorded under voltage-clamp conditions (Burgess et al., 1989). The depolarization (and spiking) produced by BK appears to be sufficient to induce the opening of the high-threshold, dihydropyridine-sensitive, L-type $\mathrm{Ca}^{2+}$ channels because the BKinduced influx of radiolabeled ${ }^{45} \mathrm{Ca}$ is markediy reduced by nifedipine (Burgess et al., 1989). This evidence suggests the following course of events: In a non-voltage-clamped DRG neuron, BK-receptor activation first opens channels that allow the 
influx of $\mathrm{Na}^{+}$that depolarizes the cell, causing action potential generation and thus the opening of voltage-activated $\mathrm{Ca}^{2+}$ channels. The increase in ${ }^{45} \mathrm{Ca}$ flux measured upon exposure to BK (Burgess et al., 1989) is a secondary effect of the depolarization; there is no evidence that $\mathrm{BK}$ directly activates $\mathrm{Ca}^{2+}$ channels. A fraction of the $\mathrm{Ca}^{2+}$ channels opened by the membrane depolarization are subsequently blocked by the exposure to $\mathrm{BK}$. In this sense, the inhibition of $\mathrm{Ca}^{2+}$ current by $\mathrm{BK}$ may serve a homeostatic role, damping the effects of depolarization on transmitter release.

The findings of Burgess et al. (1989) raise the possibility that PKC regulates the monovalent cation channels that are opened upon exposure to BK. Phorbol esters mimicked the ability of BK to depolarize DRG neurons, and both phorbol esters and OAG (1 $\mu \mathrm{M})$ mimicked the BK-induced increase in the rate of uptake of ${ }^{45} \mathrm{Ca}$. All of these effects were nearly completely blocked by the PKC inhibitor staurosporine and by downregulation of PKC by long-term phorbol ester pretreatment. These data, along with the present study, suggest that the BK-induced depolarization measured in current clamp and the BK-induced reduction of $\mathrm{Ca}^{2+}$ current measured in voltage clamp are both mediated by PKC activation. If so, BK may provide a good example of how multiple cellular actions of a neurotransmitter (Miller, 1987) can be produced by activation of one kinase pathway.

\section{References}

Baccaglini PI, Hogan PG (1983) Some rat sensory neurons in culture express characteristics of differentiated pain sensory cells. Proc Natl Acad Sci USA 80:594-598.

Bean BP (1989) Neurotransmitter inhibition of neuronal calcium currents by changes in voltage dependence. Nature 340:153-156.

Bishop WR, Bell RM (1986) Attenuation of sn-1,2-diacylglycerol second messengers: metabolism of exogenous diacylglycerols by human platelets. J Biol Chem 261:12513-12519.

Bley KR, Tsien RW (1990) Inhibition of $\mathrm{Ca}^{2+}$ and $\mathrm{K}^{+}$channels in sympathetic neurons by neuropeptides and other ganglionic transmitters. Neuron 2:379-391.

Boland LM, Dingledine R (1989) Properties of barium currents through voltage-dependent calcium channels in a dorsal root ganglion cell line, F-11. European Neurosci Soc Abstr 12:301.

Boland LM, Dingledine R (1990a) Expression of sensory neuron antigens by a dorsal root ganglion cell line, F-11. Dev Brain Res 51: 259-266.

Boland LM, Dingledine R (1990b) Multiple components of both transient and sustained barium currents in a rat dorsal root ganglion cell line. J Physiol (Lond) 420:223-245.

Boland LM, Allen A, Dingledine R (1989) Bradykinin inhibits voltagedependent barium current in a clonal population of dorsal root ganglion $\times$ neuroblastoma hybrid cells. Soc Neurosci Abstr 15:15.

Bosma MM, Hille B (1989) Protein kinase C is not necessary for peptide-induced suppression of $M$ current or for desensitization of the peptide receptors. Proc Natl Acad Sci USA 86:2943-2947.

Brown DA, Higashida $H$ (1988) Membrane current responses of NG108-15 mouse neuroblastoma $x$ rat glioma hybrid cells to bradykinin. J Physiol (Lond) 397:167-184.

Burgess GM, Mullaney I, McNeill M, Dunn PM, Rang HP (1989) Second messengers involved in the mechanisms of action of bradykinin in sensory neurons in culture. J Neurosci 9:3314-3325.

Conn PJ, Strong JA, Kaczmarck LK (1989) Inhibitors of protcin kinase $C$ prevent enhancement of calcium current and action potentials in peptidergic neurons of Aplysia. J Neurosci 9:480-487.

DeGeorge JJ, Morell P, McCarthy KD, Lapetina EG (1986) Cholinergic stimulation of arachidonic acid and phosphatidic acid metabolism in C62B glioma cells. J Biol Chem 261:3428-3433.

DeRiemer SA, Strong JA, Albert KA, Greengard P, Kaczmarek LK (1985) Enhancement of calcium current in Aplysia neurones by phorbol ester and protein kinase C. Nature 313:313-316.
Doerner D, Pitler TA, Alger BE (1988) Protein kinase C activators block specific calcium and potassium current components in isolated hippocampal neurons. J Neurosci 8:4069-4078.

Dolphin AC, McGuirk SM, Scott RH (1989) An investigation into the mechanisms of inhibition of calcium channel currents in cultured sensory neurones of the rat by guanine nucleotide analogues and $(-)$ baclofen. Br J Pharmacol 97:263-273.

Ebanks R, Roifman C, Mellors A, Mills GB (1989) The diacylglycerol analogue 1,2-sn-dioctanoylglycerol induces an increase in cytosolic free $\mathrm{Ca}^{2+}$ and cytosolic acidification of $\mathrm{T}$ lymphocytes through a protein kinase C-independent process. Biochem J 258:689-698.

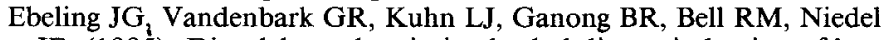
JE (1985) Diacylglycerols mimic phorbol diester induction of leukemic cell differentiation. Proc Natl Acad Sci USA 82:815-819.

Ewald DA, Matthies HJG, Perney TM, Walker MW, Miller RJ (1988) The effect of down regulation of protein kinase $C$ on the inhibitory modulation of dorsal root ganglion neuron $\mathrm{Ca}^{2+}$ currents by neuropeptide Y. J Neurosci 8:2447-2451.

Ewald DA, Pang I-H, Sternweis PC, Miller RJ (1989) Differential G protein-mediated coupling of neurotransmitter receptors to $\mathrm{Ca}^{2+}$ channels in rat dorsal root ganglion neurons in vitro. Neuron $2: 1185$ 1193.

Francel P, Dawson G (1988) Bradykinin induces the bi-phasic production of lysophosphatidyl inositol and diacylglycerol in a dorsal root ganglion $x$ neurotumor cell hybrid cell line, F-11. Biochem Biophys Res Commun 152:724-731.

Francel PC, Harris K, Smith M, Fishman MC, Dawson G, Miller RJ (1987a) Neurochemical characteristics of a novel dorsal root ganglion $\mathrm{x}$ neuroblastoma hybrid cell line, F-11. J Neurochem 48:1624-1631.

Francel PC, Miller RJ, Dawson G (1987b) Modulation of bradykinininduced inositol trisphosphate release in a novel neuroblastoma $x$ dorsal root ganglion sensory neuron cell line (F-11). J Neurochem 48: $1632-1639$.

Francel PC, Keefer JF, Dawson G (1989) Bradykinin analogs antagonize bradykinin-induced second messenger production in a sensory neuron cell line. Mol Pharmacol 35:34-38.

Gammon CM, Allen AC, Morell P (1989) Bradykinin stimulates phosphoinositide hydrolysis and mobilization of arachidonic acid in dorsal root ganglion neurons. J Neurochem 53:95-101.

Ganong BR, Loomis CR, Hannun YA, Bell RM (1986) Specificity and mechanism of protein kinase $C$ activation by sn-1,2-diacylglycerols. Proc Natl Acad Sci USA 83:1184-1188.

Hamill OP, Marty A, Neher E, Sakmann B, Sigworth FJ (1981) Improved patch-clamp techniques for high-resolution current recording from cells and cell-free membrane patches. Pfluegers Archiv 391:85100 .

Hammond C, Paupardin-Tritsch D, Nairn AC, Greengard P, Gerschenfeld HM (1987) Cholecystokinin induces a decrease in $\mathrm{Ca}^{2+}$ current in snail neurons that appears to be mediated by protein kinase $C$. Nature 325:809-811.

Harish O, Dunlap K, Role L (1986) Neurotransmitter regulation of phosphatidylinositol metabolism in embryonic sensory and sympathetic neurons. Soc Neurosci Abstr 12:803.

Hidaka HM, Inagaki S, Kawamoto S, Sasaki Y (1984) Isoquinolinesulfonamides, novel and potent inhibitors of cyclic nucleotide-dependent protein kinase and protein kinase C. Biochemistry 23:50365041.

Hockberger P, Toselli M, Swandulla D, Lux HD (1989) A diacylglycerol analogue reduces neuronal calcium currents independently of protein kinase $C$ activation. Nature 338:340-342.

House C, Kemp BE (1987) Protein kinase C contains a pseudosubstrate prototype in its regulatory domain. Science 238:1726-1728.

Huang K-P, Huang FL, Nakabayashi H, Yoshida Y (1988) Biochemical characterization of rat brain protein kinase $\mathrm{C}$ isozymes. J Biol Chem 263:14839-14845.

Kikkawa U, Nishizuka Y (1986) The role of protein kinase $\mathrm{C}$ in transmembrane signalling. Annu Rev Cell Biol 2:149-178.

Marchetti C, Brown AM (1988) Protein kinase activator 1-oleoyl-2acetyl-sn-glycerol inhibits two types of calcium currents in $\mathrm{GH} 3$ cells. Am J Physiol 254:C206-C210.

McGehee DS, Oxford GS (1988) Bradykinin induces an inward cation current and an increased membrane conductance in cultured rat sensory neurons. Soc Neurosci Abstr 14:144.

McGehee DS, Oxford GS (1989) Bradykinin-induced currents in rat DRG neurons and F-11 cells are insensitive to pertussis toxin. Soc Neurosci Abstr 15:217. 
Miller RJ (1987) Bradykinin highlights the role of phospholipid metabolism in the control of nerve excitability. Trends Neurosci 10:226228.

Murakami K, Chan SY, Routtenberg A (1986) Protein kinase C activation by cis-fatty acid in the absence of $\mathrm{Ca}^{2+}$ and phospholipids. $\mathrm{J}$ Biol Chem 261:15424-15429.

Naor Z, Shearman MS, Kishimoto A, Nishizuka Y (1988) Calciumindependent activation of hypothalamic type I protein kinase $\mathrm{C}$ by unsaturated fatty acids. Mol Endocrinol 2:1043-1048.

Nishizuka Y (1984) The role of protein kinase C in cell surface signal transduction and tumour promotion. Nature 308:693-698.

Nishizuka Y (1988) The molecular heterogeneity of protein kinase C and its implications for cellular regulation. Nature 334:661-665.

Rane SG, Dunlap K (1986) Kinase C activator 1,2-oleoylacetyl-glycerol attenuates voltage-dependent calcium current in sensory neurons. Proc Natl Acad Sci USA 83:184-188.
Rane SG, Walsh MP, McDonald JR, Dunlap K (1989) Specific inhibitors of protein kinase $C$ block transmitter-induced modulation of sensory neuron calcium current. Neuron 3:239-245.

Tamaoki T, Nomoto H, Takahashi I, Kato Y, Morimoto M, Tomita F (1986) Staurosporine, a potent inhibitor of phospholipid/ $\mathrm{Ca}^{2+} \mathrm{de}-$ pendent protein kinase. Biochem Biophys Res Commun 135:397402.

Tsien RW, Lipscombe D, Madison DV, Bley KR, Fox AP (1989) Multiple types of neuronal calcium channels and their selective modulation. Trends Neurosci 11:431-438.

Vivaudou MB, Clapp LH, Walsh JV Jr., Singer JJ (1988) Regulation of one type of $\mathrm{Ca}^{2+}$ current in smooth muscle cells by diacylglycerol and acetylcholine. FASEB J 2:2497-2504.

Wer7 MA, MacDonald RL (1987) Dual actions of phorbol esters to reduce calcium and potassium conductances of mouse neurons. Neurosci Lett 78:101-106. 